\title{
PENGGUNAAN KLAUSUL PEMILIHAN FORUM PENYELESAIAN SENGKETA PASAR MODAL YANG EFEKTIF DALAM RANGKA MENDUKUNG PEMBANGUNAN EKONOMI NASIONAL
}

\author{
(Application The Effective Choice Of Forum Clause On Capital Market Dispute Resolution To Support \\ National Economic Development)
}

\author{
Rahmanisa Purnamasari Faujura \\ Fakultas Hukum Universitas Padjadjaran \\ J. Dipatiukur No. 35, Bandung \\ Email: rahmanisaa@gmail.com \\ Muhammad Agus Salim \\ Fakultas Hukum Universitas Padjadjaran \\ Jl. Dipatiukur No. 35, Bandung \\ Email: muhammadagussalim.sh@gmail.com
}

Naskah diterima: 19 Februari 2018; revisi: 5 April 2018; disetujui: 17 April 2018

\begin{abstract}
Abstrak
Setiap perubahan kebijakan pasar modal di Indonesia dalam rangka pembangunan ekonomi nasional berpotensi menimbulkan suatu sengketa terhadap para pihak. Sebagai langkah antisipasi, para pihak akan membuat perjanjian dengan klausul yang berisikan pemilihan forum penyelesaian sengketa pasar modal. Permasalahannya, seringkali klausul pemilihan forum dalam perjanjian tersebut menjadi hambatan karena klausul tersebut merupakan klausul ambigu/nonsense. Penelitian ini membahas mengenai bagaimana penggunaan klausul pemilihan forum penyelesaian sengketa pasar modal yang efektif dalam rangka mendukung pembangunan ekonomi nasional. Metode Penelitian yang digunakan adalah yuridis normatif, dengan hasil penelitian yang menunjukkan bahwa tidak ada pengaturan khusus dalam pembuatan perjanjian bidang pasar modal. Dibutuhkan suatu konsep yang efektif dalam penggunaan klausul pemilihan forum penyelesaian sengketa pasar modal. Klausul pemilihan forum yang ambigu akan memiliki akibat hukum terhadap penyelesaian sengketa pasar modal yang tidak bisa terselesaikan secara cepat dan dapat mengganggu berlangsungnya kegiatan pasar modal. Oleh sebab itu dalam menyelesaikan sengketa dengan klausul yang ambigu, para pihak diharapkan dapat melakukan addendum atau pembuatan ulang perjanjian penyelesaian sengketa sesuai dengan konsep yang efektif.

Kata Kunci: pasar modal, klausul, forum penyelesaian sengketa
\end{abstract}

\begin{abstract}
Every change in Indonesia Capital Market Policy under the framework of national economic development will inflict a dispute to the parties. An agreement with choice of forum clause for dispute resolution on capital market are made as an anticipation. The problem is the choice of forum clause is often be nonsense/ambiguous that it becomes a barrier to solve the dispute. This study discusses how the application of choice of forum clause on capital market dispute resolution can be effective in order to support national economic development. Using normative juridical research method, this study result shows there's no special regulation for making capital market agreement. An effective concept for the usage of choice of forum clause is needed in capital market dispute resolution. An ambiguous choice of forum clause will have a legal effect on the dispute resolution where the dispute couldn't be settled quickly and can disturb the ongoing activities of the capital market. Therefore to solve a dispute with an ambiguous clause, the parties are expected to make an addendum or remake the agreement of dispute resolution based an effective concept.
\end{abstract}

Keywords: capital market, clause, dispute resolution forum 


\section{A. Pendahuluan}

Pasar modal merupakan alat pembangunan yang menghubungkan para pemakai dana yang dalam hal ini merupakan subjek hukum dalam dunia usaha maupun pemerintah dengan para pemasok dana yang antara lain adalah masyarakat baik di dalam negeri maupun luar negeri. Sebagai alat penghubung, maka sudah sewajarnya jika dalam pasar modal terdapat prasarana hukum sebagai dasar dari kegiatan, kedudukan institutional yang kuat, perangkat yang lunak maupun perangkat keras sebagai suatu sumber daya manusia yang profesional. Adapun dalam hal ini di dalam pasar modal jelas akan terdapat penegakan hukum dan pengawasan terhadap keberlangsungan dari berjalannya pasar modal.

Keberadaan pasar modal di Indonesia merupakan salah satu faktor penting dalam pembangunan ekonomi nasional, terbukti telah banyak industri dan perusahaan yang menggunakan institusi ini sebagai media untuk menyerap investasi dan media untuk memperkuat posisi keuangannya. Secara faktual pasar modal telah menjadi pusat saraf finansial (financial nerve centre) pada dunia ekonomi modern dewasa ini, bahkan perekonomian modern tidak mungkin dapat eksis tanpa adanya pasar modal yang tangguh dan berdaya saing global serta terorganisir dengan baik. ${ }^{1}$ Pasar modal berperan penting dalam meningkatkan pertumbuhan ekonomi melalui mobilisasi sumber daya keuangan dan arus masuk modal.
Perusahaan dan pemerintah sama-sama dapat mengambil manfaat dari eksistensi pasar modal. Keduanya dapat memanfaatkan berbagai instrumen keuangan di pasar modal untuk mendanai berbagai proyek jangka panjang. Sebagai contoh, pemerintah dapat menerbitkan obligasi untuk membangun infrastruktur yang tentu akan mendorong penciptaan kekayaan negara dan tentu berdampak pada pertumbuhan ekonomi domestik. ${ }^{2}$

Salah satu bentuk penegakan dan pengawasan dari pasar modal yaitu dengan adanya Undang-Undang Nomor 8 Tahun 1995 tentang Pasar Modal sebagai kepastian hukum dan dasar hukum dalam melakukan kegiatan pasar modal. Hal ini menjadikan perusahaanperusahaan yang merupakan sebuah badan hukum akan memberikan kepercayaan terhadap pasar modal yang bukan hanya sebagai alternatif investasi saja melainkan telah dijadikan sebagai bagian dari pendanaan perusahaan atau badan hukum tersebut. Selain itu terdapatnya lembaga-lembaga penunjang dan ketentuan baik perdata maupun pidana dalam undangundang tersebut menambah keyakinan badan usaha untuk melakukan kegiatan di pasar modal dewasa ini. ${ }^{3}$

Berdasarkan data Kementerian Keuangan Republik Indonesia dan Otoritas Jasa Keuangan (OJK) kepercayaan perusahaanperusahaan tersebut telah ditandai dengan adanya peningkatan secara signifikan terhadap penyebaran efek dalam kegiatan pasar modal, dan hal ini ditandai pula dengan munculnya

\footnotetext{
Faiza Muklis, "Perkembangan Dan Tantangan Pasar Modal Indonesia”, Al-Masraf Jurnal Lembaga Keuangan dan Perbankan Volume 1, No. 1 (2016): 218.

2 Mohamed Jalloh, "The Role Of Financial Market In Economic Growth", WAIFEM REGIONAL COURSE ON OPERATIONS AND REGULATION OF CAPITAL MARKET,(2009), http://www.waifem-cbp.org/v2/dloads/ THE\%20ROLE\%200F\%20FINNCIAL\%20MARKET.pdf, (diakses 17 Februari 2018).

3 Jusuf Anwar, Penegakan Hukum dan Pengawasan Pasar Modal Indonesia, (Bandung; PT. Alumni, 2008,) hlm. xv.
} 
banyaknya produk-produk baru yang berguna untuk memudahkan investor dalam menginvestasikan dananya. ${ }^{4}$

Pertumbuhan dalam pasarmodalbergantung juga pada kinerja dari perusahaan efek sendiri, dimana perusahaan efek harus selalu meningkatkan kinerja dalam mengkoordinasikan modal, dukungan teknis, dan sumber daya manusia dalam pengembangan pasar modal. Perusahaan-perusahaan harus menjalin kerja sama yang erat untuk menciptakan pasar yang mampu menyediakan berbagai jenis produk dan alternatif investasi untuk masyarakat juga, terlebih telah dijelaskan sebelumnya bahwa kegiatan pasar modal tidak hanya untuk alternatif pembiayaan saja oleh perusahaan melainkan tujuan dari adanya kegiatan pasar modal ini juga adalah untuk alternatif investasi yang dilakukan oleh masyarakat baik di dalam negari maupun di luar negeri sehingga diharapkan mampu mendorong dan menopang pertumbuhan ekonomi nasional ${ }^{5}$, karena adanya dua fungsi tersebut yaitu fungsi ekonomi dan fungsi keuangan.

Adapun salah satu faktor bagi terciptanya pasarmodal Indonesiayangtangguh dan berdaya saing global juga adalah dengan tersedianya sistem perdagangan Efek yang mampu bersaing dengan pasar modal mancanegara. Maka dari itu pemerintah terus mendorong pengembangan sistem perdagangan menuju ke tingkat efisiensi yang paling tinggi tanpa mengabaikan faktor keteraturan dan kewajaran serta senantiasa mengikuti prosedur keterbukaan pasar modal sesuai dengan standard internasional dalam kerangka memberikan perlindungan baik kepada pelaku maupun investor. ${ }^{6}$

Sejalan dengan hal tersebut, perkembangan pasar modal di Indonesia yang menjadikan banyaknya aturan atau kebijakan baru yang berkaitan tidak hanya akan memberikan dampak positif pasar modal sebagai penopang pembangunan ekonomi nasional Republik Indonesia tetapi juga menimbulkan perbedaan pendapat maupun konflik atau sengketa yang tidak dapat dihindari oleh para pihak dalam kegiatan pasar modal tersebut. Dalam hal ini tentu saja setiap adanya sengketa yang muncul diperlukan penyelesaian yang cepat dan tepat agar sengketa tersebut tidak berlarut-larut sehingga dapat merugikan para pihak dan mengganggu keberlangsungan pembangunan ekonomi nasional. Semakin banyak kegiatan perdagangan yang dilakukan maka makin besar juga resiko adanya sengketa yang harus diselesaikan, karena dalam suatu hubungan bisnis dan perjanjian, selalu ada kemungkinan timbulnya sengketa7.

Walaupun pada dasarnya tidak ada seorang pun yang menghendaki terjadinya sengketa dengan orang lain. Oleh karena dalam hubungan bisnis atau suatu perjanjian, masing-

\footnotetext{
Yuke Rahmawati,PENILAIAN KINERJA BADAN ARBITRASE PASAR MODAL INDONESIA DENGAN METODE TOTAL QUALITY MANAGEMENT, Jurnal Cita Hukum, Vol.4, HIm 243.

5 Christy Natalia Simamarta, "Efektivitas Peran Badan Arbitrase Pasar Modal Indonesia Dalam Penyelesaian Sengketa Pasar Modal Dikaitkan Dengan Undang-Undang Nomor 30 Tahun 1999 tentang Arbitrase dan Alternatif Penyelesaian Sengketa dan Peraturan Otoritas Jasa Keuangan No. 1/POJK.07/2014 tentang Lembaga Alternatif Penyelesaian Sengketa di Sektor Jasa Keuangan", Hasil Penelitian Tesis yang dimuat dalam E-Journal Students Universitas Padjadjaran, (2015), http://repository.unpad.ac.id/20833/1/Efektifitas-Peran-Badan-ArbitrasePasar-Modal-Indonesia.pdf (diakses 17 Februari 2018)

6 Idem.

7 Sudiarto, Negosiasi, Mediasi, \& Arbitrase, (Bandung: Pustaka Reka Cipta, 2015), hlm. 5.
} 
masing pihak biasanya akan mengantisipasi kemungkinan timbulnya sengketa yang dapat terjadi setiap saat di kemudian hari melalui pencantuman klausul pemilihan forum penyelesaian sengketa. Adapun sengketa yang perlu diantisipasi adalah bagaimana cara melaksanakan klausul-klausul perjanjian apa isi perjanjian ataupun disebabkan hal lainnya. Termasuk di dalam kegiatan pasar modal yang pada dasarnya peraturan perundang-undangan di Indonesia telah menyediakan sarana untuk menyelesaikan sengketa para pihak yaitu melalui proses Peradilan Umum (litigasi) dan melalui proses di luar peradilan (non-litigasi). Namun dewasa ini. penggunaan metode alternatif penyelesaian sengketa (non-litigasi) telah banyak digunakan untuk menyelesaikan sengketa pasar modal.

Sengketa yang terjadi antara pelaku pasar modal umumnya karena kebijakan dalam bidang ekonomi, yaitu karena dibutuhkannya peningkatan peranan di bidang pasar modal sehingga memungkinkan timbulnya sengketa di antara beberapa pihak. Sebagai salah satu sarana untuk menyelesaikan sengketa pasar modal, didirikanlah sebuah lembaga alternatif penyelesaian sengketa di bidang pasar modal yaitu Badan Arbitrase Pasar Modal Indonesia (BAPMI) yang berada di bawah dukungan aturan yang dikeluarkan Badan Pengawas Pasar Modal dan Lembaga Keuangan (Bapepam-LK) yang sekarang menjadi dibawah naungan Otoritas Jasa Keuangan (OJK), yaitu Undang-Undang Nomor 8 Tahun 1995 tentang Pasar Modal dan berbagai aturan Badan Pengawas Pasar Modal dan Lembaga Keuangan yang sudah berubah menjadi Peraturan Otoritas Jasa Keuangan Republik Indonesia.

Adapun BAPMI memberikan jasa penyelesaian sengketa apabila diminta oleh pihak-pihak yang bersengketa melalui mekanisme penyelesaian di luar pengadilan (outofcourt dispute settlement). BAPMI menawarkan 4 (empat) jenis penyelesaian sengketa diluar pengadilan yang dapat dipilih oleh para pihak yang bersengketa, yaitu pendapat mengikat, mediasi, adjudikasi, dan arbitrase. Melalui ke empat cara penyelesaian tersebut diharapkan akan menghasilkan putusan yang memberikan win-win solution bagi para pihak ${ }^{8}$.

Namun, walaupun adanya pengaturan mengenai cara-cara dalam penyelesaian sengketa terhadap kegiatan pasar modal tidak menutup kemungkinan masih terjadi beberapa masalah dalam praktiknya. Hal ini biasanya terjadi pada kegiatan pasar modal yang menggunakan perjanjian, dimana para pihak tidak menggunakan klausul pemilihan forum penyelesaian sengketa atau bahkan membuat suatu klausul pemilihan forum penyelesaian sengketa yang menghasilkan suatu hal yang ambigu atau menjadi timbul masalah baru dalam pemilihan forum penyelesaian sengketa dalam pasar modal. Hal tersebut dikarenakan pada kontrak mencantumkan dua pilihan forum penyelesaian yang pada akhirnya menimbullkan arti dalam menyelesaikan sengketa tersebut harus memilih dahulu forum mana yang akan menyelesaikannya, karena tidak dapat dipungkiri adanya sengketa pasar modal akan berpengaruh juga terhadap pembangunan ekonomi nasional Indonesia.

8 Frans Hendra Winarta, Hukum Penyelesaian Sengketa Arbitase Internasional dan Nasional, (Jakarta: Sinar Grafika Offset,2012), hlm. 133. 
Kebiasaan ini menjadi satu hal yang menarik untuk dikaji secara hukum. Pertanyaan yang timbul adalah, dalam pemilihan penyelesaian sengketa pasar modal, klausul seperti apa yang efektif dalam pemilihan forum penyelesaian sengketa pasar modal dalam rangka pembangunan ekonomi nasional lalu bagaimana akibat hukumnya jika tidak adanya klausul sama sekali yang berisikan mengenai pilihan forum atau penunjukan forum penyelesaian sengketa dalam suatu perjanjian yang berhubungan dengan kegiatan pasar modal terhadap pembangunan ekonomi nasional.

Tulisan ini akan lebih banyak membahas aspek legislasi dan hal-hal yang terkait dengan substansi hukum. Sehingga permasalahan hukum yang akan dibahas didalam tulisan ini adalah: bagaimana penggunaan klausul pemilihan forum penyelesaian sengketa pasar modal yang efektif dalam rangka mendukung pembangunan ekonomi nasional?, dan apa akibat hukum dari tidak adanya klausul pemilihan forum penyelesaian sengketa dalam penyelesaian sengketa pasar modal dihubungkan dengan pembangunan ekonomi nasional?

\section{B. Metode Penelitian}

Berdasarkan permasalahan dan latar belakang di atas, penelitian ini dilakukan dengan menggunakan pendekatan yuridis normatif. ${ }^{9}$ Sebagai suatu penelitian yuridis normatif, maka penelitian ini berbasis pada analisis terhadap norma hukum. Referensi juga diperoleh dari dokumen lain yang terkait seperti hasil penelitian yang telah ada sebelumnya, seminar dan/atau lokakarya, buku-buku dan jurnal ilmiah yang terkait, serta data dari berbagai media, baik cetak maupun elektronik. Tahap penelitian dilakukan melalui studi kepustakaan untuk meneliti bahan hukum primer, bahan hukum sekunder, dan bahan hukum tersier. Teknik pengumpulan data dilakukan melalui studi dokumen, yang dilakukan dengan mengkaji dokumen-dokumen tentang hukum positif. Selanjutnya Metode analisis data dilakukan melalui normatif kualitatif.

\section{Pembahasan}

\section{Penggunaan klausul pemilihan forum penyelesaian sengketa yang efektif dalam penyelesaian sengketa pasar modal dalam rangka mendukung Pembangunan Ekonomi Nasional}

Pasar modal mempunyai peran penting dalam kegiatan ekonomi secara makro sebagai alat untuk mengalokasikan sumber daya ekonomi secara optimal. Hal ini dapat dilihat pada perusahaan yang memerlukan dana lebih memandang pasar modal sebagai suatu alat untuk memperoleh dana yang lebih menguntungkan dibandingkan dengan modal yang diperoleh dari sektor perbankan. Modal yang diperoleh dari pasar modal, selain lebih mudah memperolehnya, juga biaya untuk memperoleh modal tersebut lebih murah. Di samping itu Pasar modal berfungsi juga dalam meningkatkan kinerja ekonomi melalui peningkatan pendapatan nasional, terciptanya kesempatan kerja, dan semakin meratanya hasil-hasil pembangunan bagi masyarakat. ${ }^{10}$

Pasar modal dapat diartikan sebagai pasar yang dikelola secara terorganisir dengan aktivitas

\footnotetext{
Soerjono Soekanto, Pengantar Penelitian Hukum, (Jakarta: UI-PRESS,2006), hlm. 52.

10 Sutrisno, Manajemen Sumber Daya Manusia, (Jakarta: Kencana,2013), hlm.312.
} 
perdagangan sekuritas (surat berharga), seperti obligasi, saham preferen, saham biasa, waran, dan right dengan menggunakan jasa perantara, komisioner, underwriter, dan lembaga yang lain yang ada pada pasar tersebut. ${ }^{11}$

Pengusaha sekalipun banyak menggunakan pasar modal sebagai salah satu usaha meningkatkan kemampuan usahanya, namun didalam menalankan aktivitas perdagangan di pasar modal tersebut, para pelaku pasar ataupun para pengusaha juga sering dihadapkan pada berbagai kendala, sehingga menimbulkan sengketa para pihak didalam menjalankan aktivitas perdagangannya.

Pasal 1 angka 13 POJK Nomor 1/ POJK.07/2014 tentang Lembaga Alternatif Penyelesaian Sengketa Di Sektor Jasa Keuangan menjelaskan mengenai sengketa bahwa:

"Sengketa adalah perselisihan antara
Konsumen dengan Lembaga Jasa Keuangan
dalam kegiatan penempatan dana oleh
Konsumen pada Lembaga Jasa Keuangan
dan/atau pemanfaatan pelayanan dan/atau
produk Lembaga Jasa Keuangan setelah
melalui proses penyelesaian Pengaduan oleh
Lembaga Jasa Keuangan."

Pada dasarnya sengketa pasar modal dibagi menjadi dua berdasarkan golongan hukumnya, yaitu berdasarkan hukum publik dan hukum privat. Pelanggaran-pelanggaran atau permasalahan pasar modal dalam hukum publik yakni di bidang hukum pidana dan administrasi, sedangkan pelanggaran atau permasalahan hukum privat meliputi pelanggaran-pelanggaran atau permasalahan di bidang hukum perdata, antara lain contoh seperti manajer investasi yang gagal bayar kepada nasabah atau lebih sering terjadi permasalahan dalam perjanjian antara lembaga jasa keuangan dengan konsumen atau nasabah.

Penyelesaian sengketa pasar modal di bidang hukum publik dilakukan oleh Otoritas Jasa Keuangan (OJK) sebagai lembaga pengawas terhadap berjalannya kegiatan pasar modal. OJK memiliki kewenangan untuk langsung melakukan pemeriksaan dan penyelidikan terhadap pengaduan adanya pelanggaranpelanggaran d/bidang hukum pidana dan administrasi. Sedangkan dalam hal terjadinya sengketa pasar modal hukum perdata, khususnya berkaitan dengan perjanjian para pihak pelaku pasar, didalam penyelesaiannya perlu dilihat terlebih dahulu klausul mengenai pemilihan forum penyelesaian sengketa tersebut.

Penggunaan klausul pilihan forum penyelesaian sengketa secara prinsip adalah merupakan kebebasan dari para pihak untuk memilih dan menyepakatinya forum mana yang akan digunakan jika terjadinya sutau sengketa, inilah prinsip kebebasan berkontrak yang dianut oleh sistem hukum perdata Indonesia. Jika para pihak di dalam perjanjian sudah sepakat setiap sengketa akan diselesaikan di pengadilan, maka harus ke pengadilan, dan lembaga lain menjadi tidak berwenang. Demikian pula jika para pihak di dalam perjanjian sudah sepakat setiap sengketa akan diselesaikan di lembaga arbitrase $X$, maka harus ke lembaga arbitrase $X$, dan pengadilan atau lembaga arbitrase lain menjadi tidak berwenang ${ }^{12}$.

Permasalahan dewasa ini, dalam penyelesaian sengketa khususnya dalam menggunakan forum non-litigasi yang merupakan bagian dari Alternatif Penyelesaian

1 Miswanto, Manajemen Keuangan 2, (Jakarta:Gunadarma,1998), hlm.103.

12 Bismar Nasution, Keterbukaan Dalam Pasar Modal, (Jakarta: PPs-UI,2001), hlm. 11. 
Sengketa dalam pasar modal yaitu seringkali para pihak tidak dapat menyelesaikan sengketa tersebut di Badan Arbitrase Pasar Modal Indonesia (BAPMI) karena adanya kesalahan dalam penggunaan klausul pemilihan forum penyelesaian sengketa tersebut.

Hal tersebut terjadi karena didalam penulisan klausul para pihak mengatur 2 pilihan forum penyelesaian di dalam kontraknya, misalnya klausula pilihan forum menyebutkan "sengketa akan diselesaikan melalui pengadilan atau arbitrase", atau jika tidak bisa di selesaikan melalui arbitrase akan diajukan kepengadilan" tentunya klausula itu akan menimbulkan kerancuan di dalam pelaksanaannya di kemudian hari, karena klausul tersebut seolaholah memberikan opsi kepada para pihak apakah akan membawa kepengadilan atau ke arbitrase.

Munculnya permasalahan tersebut biasanya disebabkan karena ketidaktahuan para pihak atau para pihak menganggap bahwa klausula "sengketa akan diselesaikan melalui pengadilan atau arbitrase", atau "jika tidak bisa di selesaikan melalui arbitrase akan diajukan kepengadilan" dianggap paling netral untuk mengakomodasi keinginan para pihak saat negosiasi kontrak. Di samping faktor ketidakpahaman juga biasanya para pihak dalam perjanjian tersebut juga memasukkan klausula tanpa mempelajari terlebih dahulu karakteristik industri.nya Dengan demikian sekalipun mereka sepakat menyelesaikan setiap perselisian lewat jalur Badan Arbitrase Pasar Modal Indonesia (BAPMI), namun karena mencantumkan klausul penyelesaian sengketa juga ke pengadilan, pada praktiknya klausula itu merupakan kesalahan fatal dengan konsekuensi klausula itu disebut "nosense arbitrase clause"13, dan akibatnya pengaduan yang masuk ke BAPMI tidak bisa diproses.

Untuk itu supaya para pihak yang bersengketa bisa menggunakan forum BAPMI atau Pengadilan yang harus dipilih salah satunya, didalam penyelesaian sengketa disarankan bagi pelaku industri sebelum melakukan kerjasama dan perjanjian dengan pihak lain harus memastikan dulu forum yang akan dipilih dalam menyelesaikan sengketa secara lebih jelas, karena ketidakjelasan pilihan forum menyebabkan penyelesaian sengketa sulit diakukan BAPMI. Hal ini terlihat dari hasil riset Tim BAPMI beberapa pengaduan yang masuk ke lembaga ini ternyata tidak bisa di tindaklanjuti disebabkan para pihak dalam klausul perjanjian mencantumkan klausula "nonsense arbitrase clause"14. $^{\prime 14}$.

Untuk itu pula perlu kalimat klausul yang efektif digunakan sebagai pilihan forum penyelesaian sengketa dalam pasar modal contohnya bisa dengan secara tegas memilih salah satu forum misalnya dengan pencantuman kalimat klausul sebagai berikut "Sengketa akan diselesaikan melalui mediasi BAPMI menurut peraturan dan acara BAPMI." atau apabila para pihak telah mencantumkan secara tegas misalnya sengketa diselesaikan melalui BAPMI tetapi dimungkinkan terjadinya suatu ketidaksepakatan melalui jalur mediasi pada tahap awal penyelesaian sengketa, maka para pihak dapat menggabungkan antara mediasi dengan arbitrase dengan kalimat klausul sebagai

\footnotetext{
13 Ibid.

14 Tim BAPMI, "Klausula Penyelesaian Sengketa Melalui Arbitrase Pasar Modal", Artikel Elektronik BAPMI, http:// bapmi.org/in/ref_articles13.php (diakses 9 Februari 2018).
} 
berikut "Sengketa akan diselesaikan melalui mediasi BAPMI menurut prosedur dan acara BAPMI. Apabila sampai jangka waktu mediasi tidak berhasil mencapai perdamaian, atau para pihak mundur atau tidak melanjutkan mediasi, maka akan diselesaikan melalui arbitrase BAPMI menurut prosedur dan acara BAPMI." ${ }^{15}$

Kurang pahamnnya para pihak terhadap klausul yang efektif, disebabkan juga karena masih kurangnya sosialisasi dari BAPMI yang memang baru berdiri sehingga belum sepenuhnya mengetahui bagaimana tata cara ber-acara di BAPMI. Padahal dalam penyelesaian sengketa pasar modal khususnya di bidang hukum perdata Badan Arbitrase Pasar Modal Indonesia (BAPMI) sendiri merupakan pilihan yang selalu digunakan oleh para pihak yang bersengketa dalam kegiatan pasar modal dibandingkan dengan pengadilan. BAPMI merupakan sebuah lembaga yang lahir karena karakteristik industri Pasar Modal dan merupakan lembaga yang dibentuk untuk menyelesaikan persengketaan yang muncul antara sesama pelaku pasar modal, baik persengketaan yang muncul karena aktivitas transaksi efek maupun persengketaan antara vendor atau penyedia jasa yang terlibat dalam industri ini, termasuk untuk urusan perjanjian dan kontrak yang terkait dengan investasi dan transaksi di pasar modal.

Sejalan dengan hal tersebut, perlu diingat bahwa sebagaimana yang diatur dalam Pasal 3 UU Nomor 30 Tahun 1999 tentang Arbitrase bahwa "Pengadilan Negeri tidak berwenang untuk mengadili sengketa para pihak yang telah terikat terlebih dahulu dengan perjanjian arbitrase" begitupun dalam pasal 1 angka 1
Undang-Undang Nomor 30 Tahun 1999 tentang Arbitrase yang menjelaskan bahwa "Arbitrase adalah cara penyelesaian suatu sengketa perdata di luar peradilan umum yang didasarkan pada perjanjian arbitrase yang dibuat secara tertulis oleh para pihak yang bersengketa."

Hal ini menunjukkan bahwa klausul forum penyelesaian sengketa memang harus dibuat secara efektif dan tegas karena kedua forum tersebut sama-sama tidak memiliki wewenang lagi jika salah satunya sudah dipilih dan tercantum sebagai forum yang akan menyelesaikan sengketa oleh para pihak dalam perjanjian. Adapun dengan adanya Pasal 1 angka 1 dan Pasal 3 Undang-Undang Nomor 30 Tahun 1999 tentang Arbitrase tersebut sebetulnya menjadi suatu batasan para pihak supaya terhindar dari keberadaan klausul nonsense arbitrase clause dan akan menghindarkan para pihak dari pembahasan teknis dimasa mendatang saat sengketa benar-benar terjadi pembahasan dikemudian hari akan jauh lebih sulit dibandingkan bila disusun pada tahap awal perjanjian.

Namun jika dalam hal ini para pihak telah lebih dahulu memasukkan klausul pemilihan forum penyelesaian sengketa yang ambigu tersebut, jalur penyelesaian sengketa melalui BAPMI tentu tidak akan tertutup sama sekali karena para pihak yang bersengketa itu bisa menempuh penyelesaian sengketanya melalui jalur arbitrase dengan cara antara pihak yang bersengketa harus membuat kesepakatan penyelesaian persengketaan melalui jalur arbitrase dengan memperhatikan Pasal 9 UU $30 / 1999$ yang telah mengatur bahwa "perjanjian arbitrase yang dibuat setelah munculnya

15 Ibid. 
sengketa harus dibuat secara tertulis, jika perlu berbentuk akta notaris, dan harus membuat sekurang-kurangnya hal-hal sebagai berikut:

a. mengenai masalah yang disengketakan

b. nama lengkap dan tempat tinggal para pihak dan arbiter,

c. tempat arbitrase,

d. nama lengkap sekretaris semacam panitera pengganti dalam pengadilan,

e. jangka waktu arbitrase,

f. pernyataan kesediaan arbiter dan

g. pernyataan kesediaan para pihak menanggung seluruh biaya arbitrase. Bila tidak menyebutkan salah satu dari yang tersebut di atas, maka perjanjian arbitrase menjadi batal demi hukum.

Menurut BAPMI, setidaknya adanya ada dua pilihan forum penyelesaian yang bisa ditempuh dalam menyelesaikan sengketa ini forum tersebut adalah forum pengadilan dan forum diluar pengadilan (seperti mediasi dan arbitrase). Hal ini perlu menjadi perhatian bagi pelaku industri pasar modal karena menuangkan klausula pilihan forum dengan baik di dalam perjanjian akan menghindari sengketa tambahan yang justru timbul dikarenakan bunyi klausula yang keliru (nonsense), ambigu dan/ atau tanggung.

Untuk lebih mudah, para pihak bisa mengadopsi standar klausula pilihan forum yang dikeluarkan oleh lembaga arbitrase atau mediasi yang dipilih oleh para pihak di dalam perjanjian, yang patut dicermati adalah forum yang akan dipilih dalam menyelesaikan tiap sengketa yang muncul, adapun beberapa hal penting yang perlu diketahui oleh para pihak dalam menentukan pilihan forum penyelesaian dan bagaimana menuangkannya ke dalam perjanjian, sebagai berikut: ${ }^{16}$

a. Apabila para pihak belum mencantumkan klausulapilihanforum dalam perjanjian, maka persengketaan yang muncul kemungkinan akan diselesaikan melalui pengadilan karena forum penyelesaian diluar pengadilan hanya dapat berlangsung atas dasar kesepakatan tertulis. Konsekuensinya adalah para pihak akan menghadapi proses penyelesaiaan yang cukup lama hingga putusan pengadilan berkekuatan tetap. Apabila para pihak bermaksud untuk memilih penyelesaian diluar pengadilan maka para pihak harus membuat addendum perjanjian terlebih dahulu.

b. Faktor penting yang perlu juga mendapat perhatian apabila para pihak memilih forum arbitrase sebagai bentuk penyelesaian sengketa, maka klausula dalam perjanjian penyelesaian sengketa melalui forum arbitrase perlu membuat hal-hal sebagai berikut:

1) apakah arbitrase akan dilakukan melalui suatu lembaga arbitrase atau berupa ad hoc arbitration. Jika melalui lembaga arbitrase maka harus disebutkan nama lembaganya, misalnya BAPMI;

2) memuat prosedor atau aturan arbitraseJika sudah memilih lembaga arbitrase, biasanya akan mengikuti prosedur atau aturan beracara yang diterbitkan oleh lembaga arbitrase yang bersangkutan;

3) Tempat dimana dilangsungkanya arbitrase;

4) Pilihan hukum;

16 Christy Natalia Simamarta, Op. Cit, hlm. 5. 
5) komposisi arbiter apakah tunggal atau majelis - Jika berbentuk majelis harus ganjil minimal tiga arbiter;

6) bahasa yang digunakan dalam arbitrase;

7) pernyataan penegasan dari para pihak bahwa putusan arbitrase final dan mengikat; dan

8) bagaimana pelaksanaan putusan arbitrase dan pembebanan biaya arbitrase.

Membuat klausula arbitrase dengan lengkap akan menghindarkan para pihak dari pembahasan teknis dimasa mendatang saat sengketa benar-benar terjadi pembahasan dikemudian hari akan jauh lebih sulit dibandingkan bila disusun pada tahap awal perjanjian.

Penggunaan klausula pemilihan forum dalam penyelesaian sengketa biasanya tidak digunakan dalam sengketa pasar modal perbuatan melawan hukum, karena biasanya dalam perbuatan melawan hukum melibatkan pihak ketiga dalam permasalahan tersebut. Sehingga dalam hal ini jika terjadi suatu sengketa dalam pasar modal yang merupakan perbuatan melawan hukum, maka sengketa kemungkinan akan langsung dibawa ke jalur Pengadilan namun tetap dengan batasan sebagaimana dalam Pasal 3 UU Arbitrase tentang larangan pengadilan negeri yang dilarang menyelesaikan sengketa yang sudah terikat perjanjian arbitrase.

Pada dasarnya jalur arbitrase sendiri tidak menutup kemungkinan untuk sengketa perbuatan melawan hukum diselesaikan melalui jalur arbitrase tersebut, jika memang dalam perjanjian sebelumnya telah dicantumkan kalusul pemilihan forum sengketa melalui jalur arbitrase, maka sudah seharusnya sengketa diselesaikan melalui jalur arbitrase. Hal ini mengingat sebagaimana yang diatur dalam Pasal 2 Undang-Undang Nomor 30 Tahun 1999 tentang Arbitrase dan Alternatif Penyelesaian Sengketa tidak memberikan batasan bahwa sengketa yang diselesaikan melalui arbitrase hanya sebatas wanprestasi, hal ini dapat dilihat dari penjelesannya yaitu:

"Undang-undang ini mengatur penyelesaian sengketa atau beda pendapat antar para pihak dalam suatu hubungan hukum tertentu yang telah mengadakan perjanjian arbitrase yang secara tegas menyatakan bahwa semua sengketa atau beda pendapat yang timbul atau yang mungkin timbul dari hubungan hukum tersebut akan diselesaikan dengan cara arbitrase atau melalui alternatif penyelesaian sengketa."

Berdasarkan ketentuan dalam Pasal 2 UU Arbitrase tersebut, dengan adanya nomenklatur yang mungkin timbul dari hubungan hukum tersebut, dijadikan dasar bagi pihak yang merasa dirugikan atas $\mathrm{PMH}$ untuk menyelesaikan permasalahan yang ada melalui arbitrase. Adapun salah satu alasan yang umumnya digunakan oleh pihak yang mengajukan gugatan $\mathrm{PMH}$ ke pengadilan negeri dan bukan ke arbitrase yaitu karena adanya keterkaitan pihak ketiga dengan permasalahan yang ada.

Namun demikian, Pasal 30 UU Arbitrase telah mengakomodir adanya kemungkinan proses pemeriksaan di arbitrase melibatkan pihak ketiga di luar perjanjian, yaitu:

"Pihak ketiga di luar perjanjian arbitrase dapat turut serta dan menggabungkan diri dalam proses penyelesaian sengketa melalui arbitrase, apabila terdapat unsur kepentingan yang terkait dan keikutsertaannya disepakati oleh para pihak yang bersengketa serta disetujui oleh arbiter atau majelis arbiter yang memeriksa sengketa yang bersangkutan."

UU Arbitrase sendiri tidak memberikan penjelasan lebih lanjut mengenai keikutsertaan pihak ketiga dalam proses penyelesaian di 
arbitrase. Namun, jika hanya merujuk kepada ketentuan dalam Pasal 30 UU Arbitrase tersebut, maka masuknya pihak ketiga dimungkinkan dalam suatu proses pemeriksaan arbitrase. Dengan syarat, masuknya pihak ketiga tersebut memperoleh persetujuan baik dari pihak arbiter atau majelis arbiter dan para pihak (Pemohon dan Termohon).

\section{Akibat Hukum Tidak Adanya Klausul Pemilihan Forum Penyelesaian Sengketa Dalam Sengketa Pasar Modal Terhadap Pembangunan Ekonomi Nasional}

Forum penyelesaian sengketa pasar modal yang bisa ditempuh adalah forum pengadilan dan forum di luar pengadilan (seperti mediasi dan arbitrase), hal ini ditegaskan juga oleh BAPMI yang menyatakan bahwa setidaknya adanya ada dua pilihan forum penyelesaian yang bisa ditempuh dalam menyelesaikan sengketa ini forum tersebut adalah forum pengadilan dan forum di luar pengadilan yang disebut sebagai alternatif penyelesaian sengeketa ${ }^{17}$.

Namun permasalahan mengenai ketidaktahuan atau kesalahan dalam pencantuman klausul pemilihan forum penyelesaian sengketa dalam perjanjian yang berkaitan dengan kegiatan pasar modal, membuat klausula menjadi suatu pembahasan teknis dimasa mendatang saat sengketa benar-benar terjadi di kemudian hari dan mengakibatkan tidak adanya klausula forum penyelesaian sengketa yang pasti dalam pemilihan forumnya.

Oleh karena itu para pelaku industri pasar modal, ketika akan melakukan perjanjian pasar modal hendaknya memahami dengan benar pilihan forum penyelesaian sengketa, sehingga terhindar dari klausula yang keliru, seperti kalimat "sengketa akan diselesaikan melalui pengadilan dan arbitrase", atau klausul yang ambigu, seperti kalimat "sengketa akan diselesaikan melalui pengadilan atau arbitrase", atau tanggung seperti kalimat "jika tidak bisa di selesaikan melalui arbitrase akan diajukan kepengadilan"

Adapun dampak adanya klausul nonsense tersebut, maka persengketaan yang muncul kemungkinan akan diselesaikan melalui pengadilan karena forum penyelesaian diluar pengadilan hanya dapat berlangsung atas dasar kesepakatan tertulis ${ }^{18}$ sebagaimana yang telah dijelaskan dalam pasal 1 angka 1 Undang-Undang Nomor 30 Tahun 1999 tentang Arbitrase dan Alternatif penyelesaian sengketa yaitu "Arbitrase adalah cara penyelesaian suatu sengketa perdata di luar peradilan umum yang didasarkan pada perjanjian arbitrase yang dibuat secara tertulis oleh para pihak yang bersengketa."

Hal ini memiliki arti juga bahwa jika terdapat klausul nonsense yang membuat para pihak tidak bisa menyelesaikan kasusnya di BAPMI, maka para pihak menjadi dianggap tidak memiliki perjanjian arbitrase atau tidak mencantumkan klausul pemilihan forum. Sebagaimana Pasal 1320 jo 1335 Kitab Undang-Undang Hukum Perdata yang mengatur mengenai syarat sah perjanjian, jika terdapat klausul yang terlarang maka perjanjian tersebut dianggap tidak memiliki kekuatan hukum dan dapat dikatakan batal demi hukum sehingga perjanjian dianggap tidak pernah ada ${ }^{19}$, merujuk pada Pasal 1 angka

\footnotetext{
17 Ibid.

18 Ibid.

19 Tim BAPMI, Op.Cit, (diakses 9 Februari 2018).
} 
3 Undang-Undang Nomor 30 Tahun 1999 Tentang Arbitrase dan Alternatif Penyelesaian Sengketa mengenai pengertian perjanjian arbitrase yang berupa klausul arbitrase maka hal ini mempertegas bahwa jika klausul yang tercantum tersebut merupakan klausul terlarang oleh aturan BAPMI maka perjanjian arbitrase yang dibuat para pihak dianggap juga tidak pernah ada. ${ }^{20}$

Adapun dalam hal terjadinya sengketa perdata pasar modal ini para pihak masih tetap ingin menggunakan jalur non-litigasi BAPMI maka dalam penyelesaian sengketanya para pihak harus membuat kembali perjanjian atau addendum mengenai perjanjian yang khusus membahas penunjukan forum penyelesaian sengketa seperti yang telah dijelaskan dalam Pasal 9 ayat (1) dan (2) Undang-Undang Nomor 30 Tahun 1999 Tentang Arbitrase dan Alternatif Penyelesaian Sengketa yang mengatur bahwa:

1) Dalam hal para pihak memilih penyelesaian sengketa melalui arbitrase setelah sengketa terjadi, persetujuan mengenai hal tersebut harus dibuat dalam suatu perjanjian tertulis yang ditandatangani oleh para pihak.

2) Dalam hal para pihak tidak dapat menandatangani perjanjian tertulis sebagaimana dimaksud dalam ayat (1), perjanjian tertulis tersebut harus dibuat dalam bentuk akta notaris.

Namun apabila ternyata dalam kenyataannya terdapat salah satu pihak yang menolak diadakan addendum untuk perjanjian yang mengatur secara khusus mengenai arbitrase, jika merujuk kembali pada Undang-Undang Nomor 30 Tahun 1999 Tentang Arbitrase dan Alternatif
Penyelesaian Sengketa, sengketa tersebut akan tetap dilakukan pelimpahan kembali kasus ke pengadilan negeri, karena klausul arbitrase yang merupakan bentuk perjanjian arbitrase sebagaimana dijelaskan dalam Pasal 1 angka 3 UU Arbitrase dan Alternatif Penyelesaian Sengketa telah jelas merupakan klausul terlarang yang membuat perjanjian arbitrase dianggap tidak pernah ada dan sengketa tidak bisa diselesaikan di BAPMI, maka dari itu pengadilan menjadi memiliki wewenang kembali untuk menyelesaikan sengketa tersebut.

Walaupun pada kenyatannya pengadilan sebagai salah satu cara penyelesaian sengketa yang paling dikenal, dapat dikatakan dalam hal sengketa bisnis akan selalu berusaha untuk dihindari oleh banyak pihak. karena adanya beberapa faktor yang diantaranya ${ }^{21}$ :

1. Lamanya proses beracara dalam persidangan penyelesaian perkara perdata;

2. Lamanya penyelesaian sengketa dapat pula disebabkan oleh panjangnya tahapan penyelesaian sengketa;

3. Lama dan panjangnya proses penyelesaian sengketa melalui pengadilan tersebut tentunya membawa akibat yang berkaitan dengan tingginya biaya yang diperlukan;

4. Sidang pengadilan di Pengadilan Negeri dilakukan secara terbuka, padahal disisilain kerahasiaan adalah sesuatu yang diutamakan di dalam kegiatan dagang.

Seperti dijelaskan sebelumnya bahwa penyelesaian sengketa pada pengadilan negeri tidak dilakukan secara cepat sehingga akan merugikan pihak-pihak yang terlibat dalam sengketa. Semakin lama penyelesaian suatu

20 Ibid.

21 Ridwan Khairandy, et. all, Pengantar Hukum Dagang Indonesia I, (Yogyakarta: Ghama Media, 1999), hlm.51. 
perkara, semakin tinggi biaya yang harus dikeluarkan. ${ }^{22} \mathrm{Hal}$ ini tentunya bagi masyarakat bisnis sangat tidak menguntungkan yang dapat berakibat pada keengganan investor dalam berinvestasi. $^{23}$

Penunjukan BAPMI sebagai forum yang dipilih dalam penyelesaian tiap sengketa di pasar modal memang bukan tanpa sebab. Pasalnya pergerakan industri ini serba cepat. Kalau memilih bentuk penyelesaian lewat jalur pengadilan dan hukum yang ada hampir pasti memerlukan waktu yang sangat lama sehingga akan sangat mungkin potensial keuntungan dari aktivitas transaksi berubah menjadi kerugian. Dan faktor tersebut merupakan salah satu alasan bagi industri pasar modal ini yang akhirnya akan berpengaruh terhadap pembangunan ekonomi nasional di Indonesia.

Seperti yang kita ketahui bahwa keberlangsungan kegiatan pembangunan ekonomi nasional akan bergantung terhadap upaya peningkatan pembangunan dan hasil- hasil dari kegiatan pasar modal ${ }^{24}$, hal tersebut tentunya sudah dapat menjelaskan bahwa dengan banyaknya sengketa pasar modal yang tidak terselesaikan akibat adanya klausul nonsense atau klausul ambigu dalam pemilihan forum penyelesaian sengketa pasar modal maka akan semakin banyak hambatan dalam keberlangsungan pembangunan ekonomi nasional.

Apabila arbitrase dianggap mekanisme penyelesaian yang keabsahannya sesuai dengan putusan pengadilan, maka para pihak harus memilih salah satu dari forum yang ada, karena tentunya jika menggunakan kedua forum dalam perjanjian tersebut maka

Namun perlu diketahui bahwa pada dasarnya memang dalam kedua forum penyelesaian sengketa ini memiliki hal yang berbeda terkait dengan penyelesaian sengketanya,sehingga dalam proses penyelesaian sengketa memiliki waktu yang berbeda. Adapun perbedaan dari Pengadilan Negeri dan Arbitrase yaitu ${ }^{25}$ :

Tabel 1. Perbedaan prosedural penyelesaian sengketa

di Pengadilan Negeri dan Arbitrase (BAPMI)

\begin{tabular}{llll}
\hline \multicolumn{1}{l}{ Pengadilan } & \multicolumn{2}{l}{ Arbitrase } \\
\hline 1. & $\begin{array}{l}\text { Mencari fakta kebenaran } \\
\text { berdasarkan aturan hukum acara }\end{array}$ & 1. & $\begin{array}{l}\text { Fakta dilupakan berdasarkan itikad } \\
\text { baik }\end{array}$ \\
\hline 2. & $\begin{array}{l}\text { Berdasarkan hukum dengan } \\
\text { memeriksa alat bukti. }\end{array}$ & 2. & $\begin{array}{l}\text { Menyederhanakan hukum dengan } \\
\text { bekerjasama memecahkan masalah }\end{array}$ \\
\hline 3. & $\begin{array}{l}\text { perkara berdasarkan hukum dan } \\
\text { argumen }\end{array}$ & 3. & $\begin{array}{l}\text { Bagaimana memecahkan masalah } \\
\text { dengan mencari perdamaian }\end{array}$ \\
\hline
\end{tabular}

22 Gaby Hardwicke, Briefing Note: Costs in Litigation, www.gabyhardwicke.co.uk. (diakses 3 April 2018).

23 Indriati Amarini, PENYELESAIAN SENGKETA YANG EFEKTIF DAN EFISIEN MELALUI OPTIMALISASI MEDIASI DI PENGADILAN, Jurnal Kosmik Hukum, Vol.16 Tahun 2016.

24 Kuncoro, Ekonomi Pembangunan: Teori, Masalah, dan Kebijakan,( Jakarta: Unit Penerbit dan Percetakan PN, 1997), hlm.15.

25 Sudiyana, "Pemberdayaan Peran Lembaga Arbitrase dalam Penyelesaian Sengketa Bisnis di Indonesia", Jurnal Padjadjaran Fakultas Hukum volume 4 , no.1 (2017), http://jurnal.unpad.ac.id/pjih/article/view/11508 (diakses 18 Februari 2018). 
Baik pengadilan negeri maupun jalur arbitrase sebagai alternatif penyelesaian sengketa sebenarnya memiliki nilai keadilan yang berbeda yaitu Pengadilan Negeri yang memiliki nilai keadilan secara prosedural sedangkan Arbitrase (BAPMI) memiliki nilai keadilan substantif yang artinya keadilan yang diberikan merupakan keadilan yang berasal dari keadilan substansi hukumnya tanpa memperhatikan keasalahan dari proseduralnya. ${ }^{26}$

Mengacu pada penjelasan diatas tentunya kedua forum penyelesaian sengketa tersebut memiliki nilai keadilan yang dapat berfungsi dalam meyelesaikan sengketa pasar modal walaupun dengan cara yang berbeda. Maka dari itu jika kedua forum tersebut tidak dapat digunakan dalam menyelesaikan sengketa pasar modal akibat adanya kalusul ambigu atau nonsense, hal yang akan terjadi adalah penyelesaian sengketa yang akan memakan waktu lebih lama sehingga dapat mengganggu keberlangsungan pembangunan ekonomi nasional.

Maka dari itu terhadap permasalahan mengenai adanya klausul nonsense dalam pemilihan forum penyelesaian sengketa, akan lebih baik jika terdapat suatu perbaikan atau penambahan regulasi yang mengatur secara khusus mengenai penulisan perjanjian dalam kegiatan pasar modal khususnya terhadap forum penyelesaian sengketa, baik dibuat melalui Badan Arbitrase Pasar Modal Indonesia (BAPMI) dan/atau Otoritas Jasa Keuangan seperti contohnya yang telah ada pada pasal 32 ayat 4 Undang-Undang Nomor 25 Tahun 2007 Tentang Penanaman Modal yang menjelaskan “jika terdapat sengketa penanaman modal antara Pemerintah dengan penanam modal asing, para pihak akan menyelesaikan sengketa tersebut melalui arbitrase internasional yang harus disepakati oleh para pihak." Dengan adanya regulasi tersebut maka diharapkan kedepannya tidak akan ada klausul yang bersifat ambigu atau tidak dibuatnya klausul mengenai pemilihan forum penyelesaian sengketa yang semakin menambah masalah dalam penyelesaian sengketa pasar modal.

Adapun kepentingan dari solusi ini dibuat, karena dewasa ini dalam Undang-Undang Nomor 8 Tahun 1995 tentang Pasar Modal sendiri tidak mengatur secara khusus mengenai forum yang dapat menyelesaian sengketa untuk kasus perdata serta jika merujuk pada Pasal 11 ayat (2) Undang-Undang Nomor 30 Tahun 1999 Tentang Arbitrase dan Alternatif Penyelesaian Sengketa, pasal tersebut memiliki arti bahwa pengadilan masih berwenang untuk menyelesaikan sengketa yang sekalipun telah terdapat perjanjian arbitrase namun sesuai dengan undang-undang yang berlaku, maka dari itu hal tersebut akan selalu menimbulkan persepsi yang berbeda dari setiap pihak yang tentunya akan berdampak pada dualisme penyelesaian sengketa yang tercantum dalam klausul nonsense sehingga keinginan para pihak dapat terpenuhi pada awal perjanjian.

\section{Penutup}

Penggunaan klausul pemilihan forum penyelesaian sengketa dalam pasar modal biasanya digunakan dalam suatu kegiatan pasar modal yang berkaitan dengan hukum privat atau perdatasepertiadanya perjanjianantaramanajer investasi dengan nasabah. Namun dewasa ini

26 Ibid. 
dalam perjanjian tersebut masih terdapat suatu kesalahan khususnya dalam penulisan klausul pemilihan forum penyelesaian sengketa yang dianggap sebagai klausul ambigu atau nonsense, dan pada akhirnya akan menimbulkan suatu permasalahan baru dalam penyelesaian sengketa pasar modal. Maka dari itu, sebaiknya dalam membuat suatu klausul pemilihan forum penyelesaian sengketa dalam pasar modal akan lebih efektif jika para pihak yang terkait dalam perjanjian, langsung mencantumkan forum mana yang akan digunakan dalam klausul apabila terjadi suatu sengketa pasar modal kedepannya. Walaupun pada dasarnya tidak ada aturan khusus yang mengatur namun bisa dengan mengikuti Pasal 9 UU 30/1999 yang mengatur mengenai perjanjian arbitrase yang dibuat setelah munculnya sengketa harus dibuat secara tertulis. Dengan efektifnya penyelesaian sengketa di pasar modal, otomatis akan membuat para investor semakin percaya terhadap badan pasar modal Indonesia dan semakin besar juga peluang dalam menopang pembangunan ekonomi nasional.

Tidak adanya klausul pemilihan forum penyelesaian sengketa pasar modal dalam suatu perjanjian yang berkaitan dengan pasar modal, tentunya akan memiliki suatu akibat hukum terhadap berjalannya penyelesaian sengketa jika kedepannya terjadi sengketa. Adapun akibat hukum yang terjadi adalah sengketa tersebut kemungkinan besar akan diselesaikan langsung di pengadilan tanpa menggunakan jalur alternatif penyelesaian sengketa Badan Arbitrase Pasar Modal Indonesia( BAPMI) dengan tetap adanya batasan dalam Pasal 3 UU Arbitrase yaitu larangan untuk pengadilan negeri memutus sengketa yang telah masuk dalam perjanjian arbitrase, hal ini tentunya akan membuat proses dalam penyelesaian sengketa pasar modal tersebut menjadi membutuhkan waku lama untuk selesai dan juga dalam menghasilkan hasil dari kegiatan pasar modal yang menjadi penopang dalam keberlangsungan pembangunan ekonomi nasional akan terhambat.

Dalam pembuatan perjanjian yang berkaitan dengan kegiatan pasar modal, sebaiknya para pihak bisa lebih waspada terhadap kejadian yang terjadi kedepannya. Akan lebih baik jika klausul pemilihan forum dibuat secara jelas penunjukannya, karena jika tetap ingin menggunakan jalur non-litigasi dalam penyelesaian sengketanya maka harus dibuat kembali perjanjian yang khusus membahas penunjukan forum penyelesaian sengketa seperti yang dijelaskan dalam Pasal 9 UU $30 / 1999$ yang mengatur mengenai perjanjian arbitrase yang dibuat setelah munculnya sengketa harus dibuat secara tertulis. Selain itu, sekalipun tidak ada aturan khusus mengenai penulisan perjanjian dalam kegiatan pasarmodal namun seharusnya pemerintah melalui Badan Arbitrase Pasar Modal Indonesia (BAPMI) dan/ atau Otoritas Jasa Keuangan berinisiatif untuk membuat rumusan terhadap adanya pengaturan pembuatan perjanjian dalam pasar modal seperti contohnya yang telah ada pada pasal 32 ayat 4 Undang-Undang Nomor 25 Tahun 2007 Tentang Penanaman Modal yang menjelaskan "jika terdapat sengketa penanaman modal antara Pemerintah dengan penanam modal asing, para pihak akan menyelesaikan sengketa tersebut melalui arbitrase internasional yang harus disepakati oleh para pihak." , dengan adanya solusi tersebut diharapkan kedepannya tidak akan ada klausul yang bersifat ambigu atau tidak dibuatnya klausul mengenai pemilihan forum penyelesaian sengketa yang semakin 
menambah masalah dalam penyelesaian sengketa pasar modal.

\section{Daftar Pustaka}

\section{Buku}

Anwar, Jusuf, Penegakan Hukum dan Pengawasan Pasar Modal Indonesia, (Bandung: PT. Alumni, 2008).

Khairandy, Ridwan, et. all, Pengantar Hukum Dagang Indonesia I, (Yogyakarta: Ghama Media, 1999).

Kuncoro, Ekonomi Pembangunan: Teori, Masalah, dan Kebijakan,(Jakarta: Unit Penerbit dan Percetakan PN, 1997).

Miswanto, Manajemen Keuangan 2, (Jakarta:Gunadarma,1998).

Nasution, Bismar, Keterbukaan Dalam Pasar Modal, (Jakarta: PPs-UI,2001).

Soekanto, Soerjono, Pengantar Penelitian Hukum, (Jakarta: UI-PRESS, 2006).

Sudiarto, Negosiasi,Mediasi,\&Arbitrase, (Bandung: Pustaka Reka Cipta, 2015).

Sutrisno, Manajemen Sumber Daya Manusia, (Jakarta: Kencana, 2013).

Winarta, Frans Hendra, Hukum Penyelesaian Sengketa Arbitase Internasional dan Nasional, (Jakarta: Sinar Grafika Offset,2012).

\section{Makalah/Artikel/Laporan/Hasil Penelitian}

Faiza Muklis, "Perkembangan Dan Tantangan Pasar Modal Indonesia", Al-Masraf Jurnal Lembaga Keuangan dan Perbankan Volume 1 , No. 1 (2016)

Indriati Amarini, "PENYELESAIAN SENGKETA YANG EFEKTIF DAN EFISIEN MELALUI OPTIMALISASI MEDIASI DI PENGADILAN" , Jurnal Kosmik Hukum, Vol.16 (2016)

\section{Internet}

Christy Natalia Simamarta, "Efektivitas Peran Badan Arbitrase Pasar Modal Indonesia Dalam Penyelesaian Sengketa Pasar Modal Dikaitkan Dengan Undang-Undang Nomor 30 Tahun 1999 tentang Arbitrase dan Alternatif Penyelesaian
Sengketa dan Peraturan Otoritas Jasa Keuangan No. 1/POJK.07/2014 tentang Lembaga Alternatif Penyelesaian Sengketa di Sektor Jasa Keuangan", Hasil Penelitian Tesis yang dimuat dalam E-Journal Students Universitas Padjadjaran, (2015), http://repository.unpad.ac.id/20833/1/ Efektifitas-Peran-Badan-Arbitrase-Pasar-ModalIndonesia.pdf (diakses 17 Februari 2018).

Gaby Hardwicke, Briefing Note: Costs in Litigation, www.gabyhardwicke.co.uk. (diakses 3 April 2018).

Mohamed Jalloh, "The Role Of Financial Market In Economic Growth", Waifem Regional Course On Operations And Regulation Of Capital Market,(2009)Http://Www.Waifem-Cbp.Org/ V2/Dloads/THE\%20ROLE\%20OF \%2 FINNCIAL\%20MARKET.Pdf (diakses 17 Februari 2018).

Sudiyana, "Pemberdayaan Peran Lembaga Arbitrase dalam Penyelesaian Sengketa Bisnis di Indonesia", Jurnal Padjadjaran Fakultas Hukum volume 4, no.1 (2017), http://jurnal.unpad. ac.id/pjih/article/view/11508 (diakses 18 Februari 2018).

Sudiyana, "Pemberdayaan Peran Lembaga Arbitrase dalam Penyelesaian Sengketa Bisnis di Indonesia", Jurnal Padjadjaran Fakultas Hukum volume 4, no.1 (2017), http://jurnal.unpad. ac.id/pjih/article/view/11508 (diakses 18 Februari 2018).

Tim BAPMI, "Klausula Penyelesaian Sengketa Melalui Arbitrase Pasar Modal", Artikel Elektronik BAPMI, http://bapmi.org/in/ref_articles13.php (diakses 9 Februari 2018).

\section{Peraturan}

Undang-Undang Nomor 8 Tahun 1995 tentang Pasar Modal

Undang-Undang Nomor 25 Tahun 2007 tentang Penanaman Modal

Undang-Undang Nomor 30 Tahun 1999 Tentang Arbitrase dan Alternatif Penyelesaian Sengketa

Peraturan Otoritas Jasa Keuangan Nomor 1/ POJK.07/2014 Tentang Lembaga Alternatif Penyelesaian Sengketa di Sektor Jasa Keuangan 